\title{
Io Love, Will, and the Intellectual Ascents
}

\author{
SARAH CATHERINE BYERS
}

Beloved eternity: you are my God.

(conf. 7.IO.I6)

Augustine's accounts of his so-called mystical experiences in conf. 7.IO.I6, I7.23, and 9.I0.24 are puzzling. The primary problem is that, although in all three accounts he claims to have seen "that which is," we have no satisfactory account of what "that which is" is supposed to be. I shall be arguing that, contrary to a common interpretation, Augustine's intellectual "seeing" of "being" in Books 7 and 9 was not a vision of the Christian God as a whole, nor of one of the divine persons, each of whom is equally God, according to Augustine. This becomes clear when we attend to the fact that Augustine is appropriating a specific meaning of "that which is" or "being" used by Plotinus in his account of the lover of Beauty. This resolution, however, leads to a second question. Is there anything distinctively Christian about any, or all, of Augustine's ascents? On the one hand, it would be odd if there were not, given that the Confessions are addressed to the Christian God. On the other hand, upon close inspection we find that the allegedly specific "Christian" characteristics that modern commentators have identified in the ascents of conf. 7 and 9 also occur in the Neoplatonists. I will argue that there is in fact one important difference between Augustine and the Neoplatonists here that has not been pointed out in these prior interpretations.

\section{PROBLEMATIC INTERPRETATIONS OF THE ASCENTS IN CONF. 7 AND 9}

Augustine claims that as a young man he repeatedly attained intellectual vision of "being [id quod est, esse]." These reports are located in three famous passages of the Confessions. In conf. 7.I0.I6, he recounts: "When I first came to know you, you raised me up to make me see that 
what I saw was, and that I who saw was not yet [Et cum te primum cognovi, tu adsumpsisti me ut viderem esse quod viderem, et nondum me esse qui viderem]." I In conf. 9.10.24, Augustine similarly reports:

We ascended even further by internal reflection and dialogue and wonder at your works, and we entered into our own minds. We moved up beyond them ... There life is the Wisdom ${ }^{2}$ through which all creatures come to be, both things which were and things which will be. But Wisdom itself is not brought into being but is as it was and always will be. Furthermore, in this Wisdom there is no past and future, but only being (esse), since it is eternal ... we touched it [Wisdom] in some small degree by a moment of total concentration of the heart [et adhuc ascendebamus interius cogitando et loquendo et mirando opera tua. et venimus in mentes nostras et transcendimus eas ... ibi vita sapientia est, per quam fiunt omnia

${ }^{I}$ Latin texts are taken from J. J. O'Donnell, Augustine: Confessions (Oxford: Clarendon, I992), vol. I. All English translations are from H. Chadwick, Saint Augustine: Confessions (Oxford: Oxford University Press, I99I), but sometimes, as here, these have been amended. There is an implausible alternate translation of this phrase; namely, "that I might see that there was something/being/an existing thing to see" (see P. Constantine, Confessions: A New Translation [New York: Liveright, 2018], I28; M. Boulding, Saint Augustine: The Confessions, WSA I/r [New York: New City Press, I997], I73; E. Tréhorel and G. Bouissou, Les Confessions. Livres IVII, BA [Paris: Études Augustiniennes, I992], 617; F. Sheed, The Confessions of St. Augustine, Books I-X, Ancient and Modern Library of Theological Literature I [New York: Sheed and Ward, 1942], I29), which was followed in E. Zum Brunn, St. Augustine: Being and Nothingness, trans. R. Namad [New York: Paragon House, I988 (original I978)], 69). The following authors rightly reject the alternate reading in favor of the one cited in the main text: Chadwick, Saint Augustine: Confessions, I23; J. P. Kenney, Contemplation and Classical Christianity: A Study in Augustine. Oxford Early Christian Studies (Oxford: Oxford University Press, 2013), 87; S. MacDonald, "The Divine Nature," in The Cambridge Companion to Augustine, eds. E. Stump and N. Kretzmann (Cambridge: Cambridge University Press, 200I), 7I-90, at 88, n. 30; J. Burnaby, Amor Dei: A Study of the Religion of St. Augustine (London: Hodder and Stoughton, I938), 36; O. du Roy, L'Intelligence de la foi en la Trinité selon St. Augustin (Paris: Études Augustiniennes, I966), 76, n. I. The reasons why the latter authors are correct are as follows (cf. the section titled "The Plotinian "Love" Context of All Three Ascent Passages"). It would not make sense for Augustine to present the mere realization that there was something to see as a dramatic ascent; for that information was available in simply reading the Neoplatonic books; but he presents his ascent as subsequent to reading the books, and as a deliberate act of trying to attain contemplation according to the method laid out in the Neoplatonic books. The alternate reading would make Augustine say that he had not actually attained intellectual contact with the objects proposed for contemplation in the Neoplatonic books; this contradicts his claims to have known, seen, or touched something transcendent.

${ }^{2}$ It will become clear momentarily why I have capitalized "wisdom." 
ista, et quae fuerunt et quae futura sunt, et ipsa non fit, sed sic est ut fuit, et sic erit semper. quin potius fuisse et futurum esse non est in ea, sed esse solum, quoniam aeterna est ... attingimus eam modice toto ictu cordis]. ${ }^{3}$

In conf. 7.17.23, Augustine says:

Step by step I ascended from bodies to the soul which perceives through the body, and from there to its internal power to which bodily senses report external sensations, ${ }^{4}$ this being as high as the beasts go. From there again I ascended to the power of reasoning to which is to be attributed the power of judging the deliverances of the bodily senses. This power ... had no hesitation in declaring that the unchangeable is preferable to the changeable... And in the flash of a trembling glance it attained to that which is [gradatim $a$ corporibus ad sentientem per corpus animam atque inde ad eius interiorem vim, cui sensus corporis exteriora nuntiaret, et quousque possunt bestiae, atque inde rursus ad ratiocinantem potentiam ad quam refertur iudicandum quod sumitur a sensibus corporis. Quae ... cum sine ulla dubitatione clamaret incommutabile praeferendum esse mutabili ... et pervenit ad id quod est in ictu trepidantis aspectus].

These three passages are obviously parallel in their claims that Augustine saw "what is [id quod est]." Although some scholars have wanted to partly contrast the surrounding presentation in conf. 9.10.24 with that of the two passages in Book 7, claiming that it is in some ways uniquely

${ }^{3}$ De La Peza long ago showed that the term "heart $[$ cor $]$ " in Augustine often, as here, refers to the same set of capacities as "mind [mens]" (E. De La Peza, El Signicado de "cor" en San Augustín [Paris: Études Augustiniennes, I962], 66-67, 73-76, 8I-82). Hence Augustine's statements that he "heard within the heart" and "touched being with the heart" (conf. 7.IO.I6 and conf. 9.IO.24, respectively) indicate that these experiences were acts of intellectual contemplation. Grammatically, Augustine's in plus ablative (in sapientia) need not be a locative; it could be asserting simply that, in the case of Wisdom, only the present tense - not the past or future - obtains. This is something that Augustine asserts about the Son (a.k.a. Wisdom, for Augustine) in f. et symb. 6 ad fin. Hence some of the translators render the in sapientia of conf. 9.IO.24 this way (Sheed: "it [ = Wisdom] simply is"). Most, however, have retained the literal construction "in" with the locative sense (BA, WSA). The literal construction is more accurate, given that the context of Augustine's claims to have seen "being" is, as he tells us, the "Platonic books"; see footnotes 23 and 24.

${ }^{4}$ This internal power is the internal sense [sensus interior] of conf. I.2O.3I, as well as lib. arb. 2.3.8 and 2.4.Io, on which, see S. Byers, "Augustine's Debt to Stoicism in the Confessions," in The Routledge Handbook of the Stoic Tradition, ed. J. Sellars (London: Routledge, 2016), 56-69 at 58-59. 
Christian, ${ }^{5}$ their claims do not pertain to the "being" itself of conf. 9.IO.24. It is not controversial to treat all three passages as commonly describing an apprehension of "that which is." The question is: What is "that which is"?

No doubt because Augustine's reports that he saw "that which is" are obscure, many writers have chosen not to address the question of what the intentional object of his intellectual visions was, and instead concentrated on the visions' role in his philosophical maturation (his rejection of materialism and Manichaeism). Those who do allude to the object seen typically say that it was God, without arguing for the claim that Augustine's "being" is equivalent to "God" or analyzing fully the implications of asserting that it is. ${ }^{6}$

Textually, the interpretation that Augustine is claiming to have seen God is based upon his statements in conf. 7.IO.I6 and 9.IO.24. In the former text he says that he saw a light, the light had made him, one who knows the light knows the truth, and truth is God. He says these things immediately before reporting that what he saw "was." Then, after his asseveration that he saw "what was," Augustine associates the divine name of Ex 3:I4 with his contemplation: "You cried to me from afar, 'I am who am.'" This framework certainly seems at first glance to say that he had seen God. Commentators then infer that the "being" of conf. 7.IO.I6 is God, and apply this meaning to 7.17.23 as well. In conf. 9.I0.24, Augustine says that he touched being in Wisdom, and Wisdom for Augustine is the second Person of the Trinity, who is equally God with the Father and Holy Spirit.

\footnotetext{
See the section titled "Second Problem: Christian or Neoplatonic Mysticism?"

${ }^{6}$ R. Lane Fox, Augustine: Conversions to Confessions (New York: Basic Books, 2015), 252; J. P. Kenney, The Mysticism of Saint Augustine: Rereading the Confessions (London: Routledge, 2005), 59; C. Vaught, Encounters with God in Augustine's Confessions: Books VII-IX (Albany: State University of New York Press, 2004), 53; R. J. O'Connell, St. Augustine's Confessions: The Odyssey of the Soul, third ed. (New York: Fordham University Press, 2000), 76, 79; Boulding, Saint Augustine: The Confessions, 217, n. 56, and 228, n. I03; MacDonald, "The Divine Nature," 82; J.-L. Marion, God without Being, trans. T. Carlson, Religion and Postmodernism /Chicago: University of Chicago Press, I99 I [original I 982]), 73 and 2 I 5, n. 50, following E. Zum Brunn, "L'exégèse augustinienne de 'Ego sum qui sum' et la 'métaphysique de l'Exode'," in Dieu et l'être (Paris: Études Augustiniennes, I978), I4I-I64; M. Pellegrino, Les Confessions de Saint Augustin (Paris: Études Augustiniennes, I960), I67. Exceptions are Masnovo and du Roy, but both are vague as to what Augustine did see. Masnovo, cited in Pellegrino, Les Confessions, I69, says only that immutable "being" must be a "reflection" of God rather than God. Du Roy says that Augustine saw Truth, which is God himself, but not the ultimate in God, which is eternity; eternity is known by truth, which is access to true Being (L'Intelligence de la foi, 74-75).
} 
However, earlier than and contemporaneously with the Confessions, Augustine indicates that the contemplation of the divine nature is reserved to the afterlife and requires complete moral purification. ${ }^{7}$ Given that in the Confessions Augustine presents himself as a living and morally corrupt contemplator (conf. 7.20.26-2 I.27; I0.30.42-42.67), how could he be claiming to have seen God? Although scholars continue to be interested in Augustinian "mysticism," ${ }^{8}$ this problem has not been pointed out previously, and so it has not been resolved.

\section{THE PLOTINIAN "LOVE" CONTEXT OF ALL THREE ASCENT PASSAGES}

In each of these passages, Augustine describes his experience in terms that give us no reason to doubt that he is indebted to Plotinus' descriptions of intellectual love [erōs]; namely, the desire to embrace some beauty, directed to intelligible reality (see Enn. 3.5.I). Plotinus' account is adapted from Diotima's "ladder" of love objects in Plato's Symposium, of course. ${ }^{9}$ In conf. 7.IO.I6, Augustine contrasts bodily light seen

7 The Confessions is dated to 397-400/r. Augustine says or implies that it is impossible to contemplate God's invisible nature without dying, as early as Gn. adv. Man. 5.6 (dated 388/389) and f. et symb. 9.20 (dated 393), where he cites I Cor I3:I2, "We see now through a mirror obscurely; but then face to face. Now I know in part." See also his distinction between the soul's ability to know God fully, which comes only in the afterlife, and partially, which is in this life for those who are morally purified, sol. I.7.I 4 (dated 386/387); vera rel. 7.I3 (dated 39I); c. Faust. 5.4 (dated 397/398), and Gn. litt. 8.19.38, 8.27.50 (quoting I Tim 6:I6) (begun in 40I). In the retr. I.I9.I-2, he regrets that he said in s. Dom. mon. I.4.I2 (dated 394) that it was possible for people like the Apostles to achieve in this life the complete purity of heart necessary for the vision of God. But note that even this correction addresses what he had said about the attainment of a necessary condition (non nisi; cf. also c. Adim. 9), not a sufficient one.

${ }^{8}$ Kenney, Contemplation and Classical Christianity; J.-L. Marion, "Idipsum: The Name of God according to Augustine," in Orthodox Readings of Augustine, eds. G. E. Demacopoulos and A. Papanikolaou (Crestwood, NY: St. Vladimir's Seminary Press, 2008), I67-I 89; R. Sorabji, "Time, Mysticism, and Creation," in Augustine's Confessions: Critical Essays, ed. W. Mann (Oxford: Rowman and Littlefield, 2006), 209-235, esp. 215-218; P. King, "Augustine's Encounter with Neoplatonism," The Modern Schoolman 82/3 (March 2005), 213-226; M. Gorman, "Augustine's Use of Neoplatonism in Confessions VII: A Response to Peter King," The Modern Schoolman 82/3 (March 2005), 227-233; Kenney, The Mysticism of Saint Augustine. On these works, see footnotes I, I5, I6, I9, 28, and 40.

9 According to Plotinus, all human beings are sensitive to beauty, though to greater and lesser extents. The lover matures by progressing from love of beautiful corporeal things to love of morally pure souls and sound ethical codes, to love of the various branches of scientific knowledge, to intellectual contemplation and love of immutable Beauty and Goodness themselves (cf. Plato, Symp. 2 Ioa-2 I Ic). 
by sensory eyes with the immutable light that he saw with the interior eye of his soul, that is to say, his mind. He also says that this kind of light is seen by someone who loves: love knows it [caritas novit]. He reports that during the vison he was "shocked [reverberatus]" and "trembled with love and awe [contremui amore ${ }^{\text {Io }}$ et horrore]." In conf. 7.I7.23, Augustine similarly says that he saw the "beauty [decus, pulchritudo]" of the "invisible things" "in the flash of a trembling glance." All of these characterizations are rather close to Plotinus' treatise On Beauty (Enn. I.6.4):

But about the beauties beyond, which it is no more the part of sense to see, but the soul sees them and speaks of them without instruments - we must go up to them and contemplate them and leave sense to stay down below ... There must be those who see this beauty by that with which the soul sees things of this sort, and when they see it they must be delighted and overwhelmed and excited much more than by those [bodily] beauties we spoke of before, since now it is true beauty they are grasping. These experiences must occur whenever there is contact with any sort of beautiful thing, wonder [thambos] and a shock [ekplessis] of delight and longing and love [erōs] and a happy excitement. One can have these experiences by contact with invisible beauties, and souls do have them, practically all, but particularly those who are more passionately in love with the invisible, just as with bodies all see them, but all are not stung as sharply, but some, who are called lovers, are most of all. ${ }^{\text {II }}$

Also present in Augustine's descriptions are features evocative of Plotinus' treatise On Love, which asserts that "the eternal nature is that which is primarily beautiful" (Enn. 3.5.I, line 45). In conf. 7.Io.I6, Augustine speaks of "beloved eternity [cara aeternitas]" and in 9.IO.24, he writes with erotic overtones of a rapid insight by which he

Io The various terms for "love" in Augustine are not mutually exclusive technical terms denoting different kinds of loves differentiated by different kinds of objects. Hence, in the Confessions, he speaks of philosophical love of transcendent reality by the terms amor and caritas, and he also calls the desire for money pecuniae caritas (conf. 5.12.22). See further discussion and texts in S. Byers, Perception, Sensibility, and Moral Motivation in Augustine (Cambridge: Cambridge University Press, 2013), 95-99.

${ }^{\text {II }}$ Plotinus: Enneads, trans. H. Armstrong, LCL 440 (Cambridge, MA: Harvard University Press, I966-I988), in English, amended. All translations of Plotinus are taken from this work, sometimes with amendments. 
made contact with that which he "loved"; that is, an "eternal" object for which he was sighing. Clearly, what Augustine "saw" - namely, "that which is" - was also intelligibly beautiful, and hence an object of philosophical love.

These similarities between Augustine and Plotinus are not surprising. Augustine says that he undertook his contemplative exercises in 384-386 in Milan under the tutelage of "Platonic books" (conf. 7.9.I3-I4, IO.I6), ${ }^{\text {I2 }}$ and we know for a fact that he read "books of Plotinus" in particular (in Latin translation) by $386 .{ }^{\mathrm{I} 3}$

Now these parallels between Augustine's texts and those of Plotinus allow us to figure out what "that which is" should be. Plotinus is talking in these two texts about seeing the intelligible ideas inside the Divine Intellect, the second divine entity (hypostasis ${ }^{\mathrm{I}}$ ) of his tritheistic $^{15}$ hierarchy. He says in Enn. I.6.9, lines 34-37:

First the soul will come in its ascent to Intellect and there will know the Forms, all beautiful, and affirm that these, the Ideas, are Beauty; for all things are beautiful by these, by the products of Intellect and Being.

I2 Augustine, conf. 6.I I.I8 gives his age for the move to Milan as thirty (i.e., the year 384 ), and the contemplative experiences are said to occur before his decision to be baptized (in July 386: conf. 8.II.26-27).

${ }^{13}$ In b. vita I.4 (dated 386), Augustine says that he read books of Plotinus (libri Plotini); he also mentions Plotinus in sol. I.4 (dated 386/387), c. Acad. 3.I 8 (dated 386). Presumably these were the (nonextant) translations of Marius Victorinus (see conf. 8.2.3). So, pace M. Nussbaum, Upheavals of Thought: The Intelligence of Emotions (Cambridge: Cambridge University Press, 200I), 53I, n. 3, there is no doubt that Augustine read works by Plotinus (in a Latin translation). See O'Donnell, Augustine: Confessions, vol. 2, 42I, and J. Rist, "Plotinus and Christian Philosophy," in The Cambridge Companion to Plotinus, ed. L. Gerson (Cambridge: Cambridge University Press, 1996), 386-4I 3.

${ }^{14}$ Porphyry calls Plotinus' three Gods "hypostases" in his headings in the fifth Ennead.

I5 Pace P. Athanassiadi and M. Frede, "Introduction," in Pagan Monotheism in Late Antiquity, ed. P. Athanassiadi and M. Frede (Oxford: Clarendon Press, I999), I-20, at 3 (cf. Kenney, Contemplation and Classical Christianity, I4), the monarchist polytheism of Plotinus is not accurately redescribed as monotheism. The point at issue in whether a theistic system is monotheistic or polytheistic is whether there is more than one god who is "divine" in the same sense. Neoplatonists like Plotinus think that immutability is the necessary and sufficient condition for being a God, and that there is more than one immutable entity, hence more than one God. To give just one of many examples, Plotinus begins Enn. I.2.I by asking "to which God" (mentioning the World Soul and Divine Intellect as two options) we are made similar by virtue. In contrast, Christian Neoplatonists such as Augustine assert that there is only one immutable entity, hence only one God; all creatures are mutable and therefore cannot be divine in the same sense as God, even if they can become "godly" by participation in the holiness of God (cf. f. et symb. 9.I6). 
Similarly, in Enn. 3.5.I, lines 32-36, Plotinus asserts that the eternal nature, which is primarily beautiful, is an "archetype" known by recollection. So prima facie, given Augustine's use of Plotinus, we should expect the object seen in the contemplative ascents in the Confessions to be a Form in the Divine Intellect.

This is in principle a plausible reading of Augustine's mystical ascents in the Confessions. Augustine had said just before writing the Confessions, in his 83 Questions (compiled in 388-395), that the Platonic Forms are the proper objects of contemplation (div. qu. 46.2 ad fin), and that these are contained in the Divine Intellect [divina intelligentia continentur], also called the Wisdom of God or Son of God (div. qu. 46.2 with questions I6, 23, 78 [a gloss on Jn I:3, "all things were made through him"], and 80). Then, in conf. 7, Augustine alludes to this Christianized Neoplatonic model when he says that the Platonists helped him to accept the Nicene account of the Son. ${ }^{16}$ Thus it is possible that in our passages of conf. 7 and 9 he is telling us that he accessed Form within the second hypostasis or person of the Christian Trinity, ${ }^{17}$ who is

I6 What he literally says is that the Platonists had an account of the Son as having the same nature as the Father (conf. 7.9.I4), a reference to the Council of Nicaea's (325 CE) doctrine of "consubstantiality." The literal statement is inaccurate; Plotinus says clearly that the One/Good/Father (cf. Augustine's Father) is essentially superior to the Divine Intellect (cf. Augustine's Son/Wisdom) (e.g., Enn. 5.I.6, line 39). Either Augustine does not mean this literally, but means that Neoplatonism was an aid to his accepting the Nicene account of consubstantial Father-Son (I incline to this interpretation), or he is genuinely confused (presumably because he had not read all of the Enneads) and thinks Plotinus actually believed that the One and Divine Intellect were "consubstantial," as in Nicaea. A third possibility, that Augustine's "Platonists" is meant to include Marius Victorinus' pro-Nicene treatises on consubstantiality, seems to be ruled out by the fact that Augustine says the Platonists did not believe in the Incarnation, something to which Victorinus refers in these treatises. (For more on Victorinus' treatises and Augustine's eventual knowledge of them hinted at later in the Confessions, see the section titled "Which Form(s) Did Augustine See?") King takes Augustine literally, and supposes that he understood Plotinus' three divine principles to be triune, the same as the Father, Son, and Holy Spirit ("Augustine's Encounter with Neoplatonism," 2 I6-2 I 8). Gorman takes issue with King, arguing that the passage is not really about all three persons of the Trinity, but about the divinity of the Son, and that in any case King has not shown how Augustine would have interpreted the three Plotinian hypostases as anything other than three distinct entities (i.e., tritheism rather than triunity/ Trinitarianism), given what King himself says about the meaning of hypostasis at the time of Augustine, and what Augustine says about its Latin translation in De Trinitate ("Augustine's Use of Neoplatonism in Confessions VII," 230-232). King's article could have benefited from the work of Ayres cited in footnote 45.

${ }^{17}$ For these terms hypostasis and persona, see Augustine, Trin. 7.4 and I 5.3; Marius Victorinus, Adv. Ar. 3.4. 
called Wisdom in the Bible, ${ }^{18}$ and who Augustine considers analogous to the second Plotinian hypostasis, which Plotinus also called "Wisdom [sophia]" (e.g., Enn. 5.8.4, line 36-5.8.5, line 25).

But why should Augustine use the term "that which is" or "being" to refer to transcendent Form? The answer to this is not difficult to discover; it lies in Plotinus' Enn. 5.8-9. It has been missed, however, by commentators who have assumed that Augustine was talking about seeing the nature of God and thus tried to make comparisons with texts wherein Plotinus describes contemplation of the One or the Good. ${ }^{19}$ In fact, Plotinus states emphatically that the One or the Good is "beyond being/s." ${ }^{20}$ So texts about vision of the One or Good are not actually relevant to Augustine's claims to have seen "being." $2 \mathrm{I}$

Plotinus' Enn. 5.8.I, On the Intelligible Beauty, asks how it is possible to ascend to contemplation of Forms in Divine Intellect, as distinct from seeing the Good that is superior to Divine Intellect. At various points in Enn. 5, Plotinus refers to a single Form as a "being [to on]," and to the multiple Forms as "beings [ta onta]."22 The Forms are contained in the second divine hypostasis, Divine Intellect or Wisdom (e.g., Enn. 5.9.5, lines 24-25). Thus, in this idiom, the participle "being" is not typically a generic term meaning "immutability" or "immutable existence," but rather is used with the definite article, and in the plural, to designate the specific immutable Forms such as Prudence, Justice, et cetera. Hence Plotinus says of ascent to the vision of a Form in Divine Intellect:

All those who are able to see look at him [Divine Intellect] and what belongs to him when they see; but each does not always gain

I8 I Cor I:24 ("Christ the power of God and the wisdom of God").

I9 So Sorabji, "Time, Mysticism, and Creation," 217; R. J. O'Connell, St. Augustine's Early Theory of Man (Cambridge: Belknap, I968), 207; P. Henry, Plotin et l'Occident (Louvain: Spicilegium Sacrum Lovaniense Études et Documents, I934), II2-I I5; Burnaby, Amor Dei, 34, n. I, citing Enn. 6.7.36. See the loci classici (but these themselves cite earlier studies): P. Courcelle, Recherches sur les Confessions de Saint Augustin (Paris: De Boccard, I968), I57-I67; Solignac's notes and commentary in the Bibliotheque Augustinienne translation: Les Confessions, second ed. (Paris: Études Augustiniennes, I992), vol. I, esp. 679-689.

20 E.g., Plotinus, Enn. I.6.9, lines 37-39; Enn. 5.r.8, lines 6-8 (referencing Plato).

${ }^{21} \mathrm{O}^{\prime}$ Connell came the closest to seeing the centrality of Plotinus' Enn. 5.8, but like the other commentators he made no use of Enn. 5.9, and by including references to other Enneads that are not relevant, he showed that he did not quite see what is at issue (St. Augustine's Early Theory of Man, 207-217).

${ }^{22}$ E.g., Plotinus, Enn. 5.I.7, lines 2 I-23; 5.8.9, lines 40-42; 5.9.5, line I2; 5.9.6, line 3; 5.9.Io, line I4. Ōn, ousa, on is the (masculine, feminine, and neuter nominative singular) present participle of the infinitive "to be [einai]." The neuter plural is onta. 
the same vision, but one, gazing intensely, sees the source and nature of Justice, another is filled with the vision of Prudence.

(Enn. 5.8.IO, lines I I-I 4 )

The historical-philosophical context for Plotinus' language of "beings" "in" Wisdom is twofold. First, as Plotinus himself notes, this use of the present participle "being" as a term of art for Form goes back to Plato, who called Form "being [on]" (e.g., Enn. 6.2.I; cf. Plato, Rep. 484c, 507b, $509 \mathrm{~b})$. Second, Plotinus is taking a position on the epistemological and metaphysical debate between Plato and Aristotle about whether Forms separated from matter exist extramentally or only in the mind. ${ }^{23}$ Plotinus famously synthesized the two by holding that there are transcendent Forms that are in a Divine Intellect. Hence he, along with Porphyry after him, makes clear that the multiple "beings" or Forms are "in" Divine Intellect, Wisdom, or Beauty in the sense of within [endon] as opposed to outside of [ouk exō] it. ${ }^{24}$

Augustine's phrase "that which is [id quod est]" in conf. 7.I7.23 is equivalent, in Latin, to the Greek participle to on ("the thing which is"). His verbal noun "being [esse]," which he says is "in Wisdom" in conf. 9.I0.24, could in principle be a rendering of this Plotinian "being" as well, given that classical Latin has no proper present participle for the verb "to be." ${ }^{25}$ So, it is plausible that Augustine is saying he saw a Form, called a "that which is," or a "being," by Plotinus. But in what sense is a Form a "being"?

${ }^{23}$ Aristotle used the language of the "place of the forms [topos eidōn]" in Anim. 3.4 429a27-28.

${ }^{24}$ E.g., Plotinus, Enn. 5.5.I, lines 50-56; 5.9.8, lines II-I 5; cf. Porphyry, Vita Plotini, I8.

${ }^{25}$ As is pointed out in a work sometimes attributed to Augustine, gramm. 4.3 I. Cf. the discussion in E. Bermon, "Grammar and Metaphysics: About the Forms essendi, essendo, essendum, and essens in Augustine's Ars grammatica breviata (IV, 3 I Weber)," Studia Patristica 54 (2012), I-IO. On one occasion, Augustine hesitantly gives essens when searching for a translation for the Greek participle "being" (loc. in Hept. 3.32 [Lev I3:46]). But the fact that Augustine does not elsewhere make use of essens shows that he does not really countenance it. Bermon suggests that Victorinus, through an oral tradition via Simplicianus, is the/a source for this term essens in Augustine (Bermon, "Grammar and Metaphysics," 5 and 9); but this is hard to reconcile with the facts that (a) Victorinus himself gives ens rather than essens as a translation in Expl. Cic. Rhet. I.28, and (b) if Victorinus were the purveyor of essens, we would expect to see him using it in his anti-Arian works, where in fact he instead leaves the participle in Greek (Adversus Arrium and Ad Candidum Arrianum [= De generatione divini verbi]), although he sometimes does translate the plural ta onta into Latin, as ea quae sunt. 
"Being" has, in principle, veridical, existential, and predicative senses. The veridical (something is the case, a proposition is true) is rather clearly the incorrect sense for our present Confessions passages. Augustine's presentation in these particular passages differs substantially from others wherein he describes his seeing that some propositions he had read in the "Platonic books" were true. ${ }^{26}$ Among other dissimilarities, here in conf. 7.I0.16, 9.10.24, and 7.17.23, he says that what he saw had made him; that he touched Wisdom in which is being, and that he saw in a flash the invisible realities of God. He can hardly be saying that he was made by true propositions, or that there are propositions in God (since propositions are not simple). Furthermore, the explicit context of the "Platonic books" indicates that this would be a misunderstanding. As we have already noted, to see "that which is" in a Neoplatonic context would not be to recognize that God is immutable and immaterial; it would be to see an eternal Form, each of which is a divine idea.

As for the existential sense, we will be especially tempted to assume that "being" is equivalent to "God" in these passages if we classify Augustine as a figure to be grouped with medieval "onto-theologians" for whom "being" means "existence." Aquinas, the most famous defender of this thesis, carefully distinguished existence [esse] from nature or essence [essentia], and then asserted that these two are united in the case of God, who is defined as pure existence [esse tantum], a subsistent thing whose essence is its existence. ${ }^{27}$ However, we should not assume that Augustine's "being" in Books 7 and 9 means "existence," given that he has told us he attempted these ascents on the basis of what he read in the Platonic books. ${ }^{28}$

${ }^{26}$ So Augustine, conf. 7.II.I7-I2.I8, I5.2I; cf. footnote I.

27 Aquinas, De ente et essentia I.I, 4.6, 5.I (chapter divisions cited here are according to the numbering in A. Maurer, Thomas Aquinas: On Being and Essence, second ed. [Toronto: Pontifical Institute of Mediaeval Studies, I968]).

${ }^{28}$ Marion is correct that, for Augustine, God is not "being" in the way that he is for Aquinas ("Idipsum," I 84-I85); but Marion does not parse out the possible senses of the term nor avert to the fact that Augustine's glossing of esse and idipsum as connoting immutability is derived from Platonic ontology. Moreover, Augustine's presentation cannot be characterized as Biblical rather than ontological or metaphysical (so Marion, "Idipsum," I79-I80, and I84). For Augustine this would be a false dichotomy, since he thought that the primary author of Scripture is God, who knows (Platonic) metaphysics and intends to tell us about it in verses such as Ex 3:I4 and Ps I2I:3 (LXX). 
In fact, the Platonic technical term "being" for the Forms uses the predicative sense of "is." ${ }^{29}$ It is a term of art for things that stably remain what they are. Clearly, the only thing that fully has the characteristic of "being," when "being" is thus defined, is an immutable object that eternally remains the same kind of thing that it is. In other words, only an immutable subsistent form is fully "being" in this sense. Accordingly, it is because Justice is just absolutely and eternally that it is called the "being [just]" in which all just particulars participate. What the individual Forms have in common, then, is that they are all being absolutely and eternally whatever it is that each one is being; hence they are called "beings." 30 Although it is counterintuitive for English speakers, when Platonists say that something "is" without qualification, they assume the listener will ask "Is what?", allowing them to mention the predicative adjective. ${ }^{3 \mathrm{I}}$

So existence is not at issue in Plotinus' use of the present participle "being." The objects of the transcendent realm exist, and the objects of the mutable spatiotemporal realm exist; only the former are called "beings," while the latter are said to be "becoming." This latter term of art "becoming [genesis]" again goes back to Plato (Tim. 27d-28a) and designates objects that are subject to any sort of change - not just coming into existence, but the gain or loss of a quality, a quantity, a relation, and so on (e.g., Plotinus, Enn. 5.9.5, lines 32-48).

Notice in this regard that all our focus passages from the Confessions have the Plotinian motif of being versus becoming. Augustine says

${ }^{29}$ See, for example, the use of "is" and "to be" in Plato's Rep. 479b-c within a discussion of the predication of properties (beautiful, just).

${ }^{\circ}$ Kahn's discussion, citing Lesley Brown's study of Plato's Sophist and Laws, is apropos here: "She [Brown] shows that the relation between einai in sentences of the form $X$ is and $X$ is $Y$ is like that between the verb teaches in Jane teaches and Jane teaches French. This seems true not only for Plato but also for Aristotle and for the language generally. Adding a predicate to einai does not change the meaning of the verb any more than adding a direct object to teaches changes the meaning of the verb to teach. From the point of view of transformational grammar, the longer form is more basic: $X$ teaches is derived from $X$ teaches something by zeroing the direct object. Similarly, I suggest, $X$ is can be derived from $X$ is $Y$ by zeroing the predicate ... Logically speaking, every absolute or existential sense of einai can be seen as an abridged form of some predication" (C. H. Kahn, The Verb "Be" in Ancient Greek: With a New Introductory Essay, second ed. [Indianapolis: Hackett, 2003], ix-x).

${ }^{31}$ This is the source of the problem of self-predicating Forms, raised by Plato in Parm. I 32a. It is because the sense in which the Form of largeness is a "being" is assumed to be its "being large" that the so-called third man problem arises. Plotinus, for his part, has no qualms about asserting that a human being here in this world below is human, and the Form/"being" Human Being contained in Divine Intellect is human, although one as image and the other as paradigm (Enn. 6.2.22, lines 42-46). 
in the excerpt from conf. 7.IO.I6 quoted in the section titled "Problematic Interpretations of the Ascents in conf. 7 and 9" that what he saw was [esse], and that he who saw was not yet [nondum esse]. If we took "to be" in the existential sense rather than as the first of a pair of Platonic terms of art, then by this self-description Augustine would be saying that he did not exist yet. This of course is absurd. The correct reading is that "not yet" is a reference to the term of art "becoming." Augustine is saying that he, the seer, belonged to the realm of comingto-be-and-passing-away, whereas what he saw did not. Compare conf. 9.IO.24, where he says that, unlike the items in temporality, Wisdom does not come to be [fieri]: "those things come into being, both those things which were and which will be. But Wisdom itself is not brought into being but is as it was and always will be." The passage in conf. 7.I7.23 similarly contrasts "that which is" immutably, with the objects of this changeable realm.

\section{AUGUSTINE WAS KNOWING ONE DIVINE IDEA}

Turning now to the details of these Confessions passages, let us consider four types of evidence for our theory that, when Augustine says that he saw "that which is," he does not mean that he contemplated God, but that he contemplated a Form within God. We have already mentioned the high antecedent probability that the contemplative achievements recounted in the Confessions are intended to be the intellectual "seeing" of Form, given what he said in his div. qu. $46.2,{ }^{32}$ and given that "that which is" is a technical term for Form in Neoplatonism. In the same text, as well as in works he wrote after the Confessions, Augustine makes clear that he held that there are multiple Forms in the Divine Intelligence (div. qu. 46.2). (He does not address the question of how God is still simple while having multiple divine ideas, although it is clear that he does hold this [see conf. 4.I6.29].) Augustine must hold, then, that, if someone were to see one of the Forms, she would not be seeing the Godhead itself.

First, there are a number of distinctive items in Plotinus' accounts of Divine Intellect, or Beauty, and of ascent to this intelligible realm,

${ }^{32}$ Note the absence here of "being" as a name for Form. The reason is that in De diversis quaestionibus Augustine is not working directly off of Plotinus or Porphyry, but instead references a doxography offering a history of philosophy (perhaps it was Varro's De philosophia). Augustine signals his Neoplatonism here, however, by saying the Forms are contained in the Divine Intellect (divina intelligentia). 
which appear also in Augustine's ascent passages in the Confessions. These distinctive elements occur in Enn. 5.8-9, where Plotinus also calls Form "that which is." Augustine repeatedly says that what he accessed was "there [ibi]" (conf. 9.IO.24, twice). This is reminiscent of the way that Plotinus uses the word "there [ekei]" as a technical term to refer to the place of the Forms, Divine Intellect (e.g., Enn. 5.8.4, 9.6, 9. Io). Again, Plotinus says that Divine Intellect is a light that "shines bright and fills those who come to be there"; it is as if it is "dawning upon them from on high" and "illuminates everything and fills it with his rays," "shocking" their intellectual power of sight (Enn. 5.8. I0, lines 5-7 and 25-26). ${ }^{33}$ This language of a superior light is also used by Augustine, who says that, when he saw a "being," he saw "an immutable light higher than his mind," which shone with radiant rays and "gave a shock to his mental sight" (conf. 7.I0.16, I7.23). Plotinus compares the contemplative vision of a Form to eating nourishing food: truth is the food of those who contemplate the beings rather than things that are coming to be (Enn. 5.8.4, lines I-4). Augustine similarly says that the being, truth, or light that he saw was "the food of the fully grown" on which he was "feeding" (conf. 7.Io.16). ${ }^{34}$ And when Augustine says that the transcendent light, or Wisdom, made all things (conf. 9.IO.24), this too is already in Plotinus, who says that Divine Intellect or Wisdom has made all things that come into being and pass away (Enn. 5.8.5).

Notice, second, that in all three passages Augustine says things that seem to imply that he was not seeing the nature of God itself. He does not in fact claim to have seen "your invisible nature," pace Chadwick's and Constantine's translations of conf. 7.17.23. Augustine says that he saw "your invisible things [invisibilia tua]," a phrase more suggestive of the Plotinian invisible "beings" known by the lover of intelligible

33 The suggestion of Theiler that Augustine's "shock of sight [ictus aspectus]" (conf. 7.17.23) is from Plotinus' Enn. 5.5.7, line ro [athrooss] would be convincing were it not for the fact that 5.8.Io has the same idea [exeplexxe, line 7] in addition to the other similarities to conf. 7.IO.I6 and 7.I7.23 that are already noted (W. Theiler, Forschungen zum Neuplatonismus [Berlin: De Gruyter, 1966], 237).

34 Cf. Augustine, conf. 7.17.23 ad fin.; 9.10.24. The parallel between eating in the two texts was noticed by O'Connell, St. Augustine's Early Theory of Man, 2 I 2. Kenney suggests that there is a Eucharistic allusion here (The Mysticism of Saint Augustine, 58). The phrase most suggestive of Eucharistic imagery is Augustine's claim that he would be transformed into what he was eating; but in fact this seems to mean that he would become wise by seeing an Idea in Wisdom, beautiful by seeing a Beauty (cf. Plotinus, Enn. 5.8.II). For Augustine next says that the food became incarnate. So the "food" is the eternal truth, metaphysically prior to the Incarnation and therefore to the Eucharist. 
beauty, than it is of the singular nature of the Trinitarian Godhead. In conf. 7.IO.I6, Augustine asserts distance between himself, the seer, and God - when he says that in the very moment of the vision, the speaker of "I am who am" called to him from afar. This would be odd if he meant that he attained union with God himself. Furthermore, he says that he was struck by "rays of" God and that God "showed him that what he saw was." Both of these suggest that the "being" he saw was not strictly identical to God. Finally, in conf. 9.10.24, Augustine claims that he touched Wisdom in some small degree [modice], and says that he "sighed [suspirare]" after it. Taking into account the philosophical context, "some small way" most plausibly means that he had seen partial content of the Divine Mind, rather than the whole of it. The term "sighed [suspirare]" was shown by Courcelle to indicate an incompletely satisfied desire (conf. 9.IO.24-25). ${ }^{35}$ Now clearly, to see partial content of the Divine Mind, that is, to see a Form, would not be entirely satisfying, given Augustine's repeated assertion in the Confessions that our hearts were made to rest in the contemplation of the "face" of God. A Form would be analogous to one of God's features rather than his face, to continue the metaphor. Notice, too, that to describe the knowledge of a single Form as incompletely satisfying would be in agreement with Plotinus, who actually says that contemplation of a single Form is not a satiating experience, because there are other Forms to know: "There is a lack of satisfaction in the sense that fullness does not cause contempt for that [i.e., being/Form] which has produced it: for that which sees goes on seeing still more" (Enn. 5.8.4, lines 3I-33). ${ }^{36}$ Clearly, if Augustine describes his experience as unsatiating, then he cannot be saying that he saw the Son, ${ }^{37}$ even momentarily. He thinks the Son is

35 Courcelle, Recherches sur les Confessions, 224-245, cited in O'Donnell, Augustine: Confessions, vol. 3, I30.

${ }^{36}$ Plotinus here describes Divine Intellect's knowledge of its own discrete Forms; but the description would certainly apply, and apply preeminently, to human minds, which must know each Form successively if they know more than one.

37 A view put forth, notably, by S. Menn, Descartes and Augustine (Cambridge: Cambridge University Press, I998), I4O-I4I, I 54-I55. This interpretation also seems to be implied by: H. Chadwick, Augustine, Past Masters (Oxford: Oxford University Press, 1986), 23; Burnaby, Amor Dei, 37-38, 4I; Zum Brunn, St. Augustine: Being and Nothingness, 7I. Note that in conf. 9.10.24, Augustine says that he and Monnica ascended in idipsum, literally into idipsum, into God (specifically, into the Son/God's Mind), and does not say that he saw idipsum. In en. Ps. I 2 I.5-6 (cited by Marion, "Idipsum," I80-183), which is not about "seeing" being, Augustine actually calls the Son "being" [esse, id quod est, idipsum], in the same way that Plotinus sometimes uses synecdoche of part for whole ("being" for Divine Intellect as a whole, Enn. 5·3.5, lines 26-28). Augustine's usage in en. Ps. 
God, ${ }^{38}$ and that contemplative union with God is sufficient for happiness (e.g., conf. I.5.5).

Third, Augustine's citation of Ex 3:I4 ("I am who am [Ego sum qui sum, in Augustine's Latin]") in conf. 7.Io.I6 very likely signals that he is partly indebted to Marius Victorinus's anti-Arian treatises here. Victorinus, writing in the late 350 o after having become a Christian, had "Niceanized" the Neoplatonic hypostases by making the Son or Divine Logos the site of the Platonic "beings" or Forms, explicitly citing Ex 3:I $4 .{ }^{39}$ Victorinus' justification for the attribution was that the (Plotinian, Porphyrian) immutable "beings [onta]" are proper to the second hypostasis, and that the Septuagint of Ex 3:I4 used this participle "being" when it said "I am he who is [ego eimi ho ōn]." ${ }^{\prime \circ}$ Augustine tells us plainly that he wanted to imitate Victorinus as soon as he heard about the famous man's conversion to Christianity from Simplicianus, Victorinus's much younger friend (presumably pupil), and that this occurred after he had already read Victorinus's translations of "the Platonists" (conf. 8.2.3). What would have been more natural than for Simplicianus to recommend that Augustine read the works that Victorinus had written as a Christian, the anti-Arian treatises, and for Augustine to follow up the suggestion eagerly? Augustine even seems to hint that he did so: Victorinus's anti-Arian treatises explain and rebut Photinus' position $(A d v$. Ar. IA.28, 2.2), and Augustine tells us that he learned how Photinus' account of the Incarnation differed from the standard Christian view somewhat after [aliquanto posterius] he read the Platonists (conf. 7.19.25) ${ }^{4 \mathrm{I}}$ he tells us this shortly before he

I 2 I.5-6 is probably not directly from Plotinus, however, but from Victorinus, $\mathrm{Ad}$ Cand. I4, lines 25-27, where again "seeing" being is not at issue.

${ }^{38}$ We know that he held this from very early in his writing career, prior to the Confessions; it is evident throughout the On True Religion, for example.

${ }^{39}$ For Victorinus explicitly equating "being [on]" in the Son with Form (forma), see Adv. Ar. 2.4, lines I9-22. By "Niceanized," I mean the creed of the Council of Nicea in 325 , which called the Son "consubstantial" with the Father.

40 Victorinus, Ad Cand. I4, lines 22-27: "This is Jesus Christ. For he himself said, 'If it will be asked: who sent you? Say, 'He who is [ho ōn].' For only that being [on] which is always being [on] is he who is [ho onn]'" (M. T. Clark, Theological Treatises on the Trinity, FC 69 [Washington, DC: The Catholic University of America Press, 200I]), in English. Pace Theiler there is no reason to think that Philo of Alexandria's mention of Ex 3:14 in Life of Moses I.75 is relevant to Augustine in conf. 7 (Forschungen zum Neuplatonismus, 237).

${ }^{41}$ Note that B. Dobell's thesis in his Augustine's Intellectual Conversion (Cambridge: Cambridge University Press, 2009), 75-I07 that Augustine was a Photinian until 395 is problematic, for more than one reason; see Byers, Perception, Sensibility, and Moral Motivation in Augustine, I85, n. 6r. 
introduces Victorinus himself in conf. 8.2.2. We also have a textual reason to think that Augustine had read Victorinus's anti-Arian treatises before the Confessions, perhaps much earlier. Augustine had already asserted that the Son of God was the subject of Ex 3:I4 in his f. et symb. 4.6, written a few years before he started the Confessions; and he had done so in the same context as Victorinus. ${ }^{42}$ So it looks like Augustine is using Victorinus's exegesis of Ex 3:I4 in the Confessions as well as On Faith and the Creed. This in turn makes it likely that the "being" Augustine claims to have seen in Confessions refers to Form contained in the Divine Intellect or Logos, rather than to the nature common to all three persons or hypostases of the Godhead.

\section{WHICH FORM(S) DID AUGUSTINE SEE?}

We have seen a few reasons to conclude that when Augustine tells us in Books 7 and 9 of the Confessions that he saw "that which is," he is not claiming to have seen God as a whole or one of the divine persons, each of whom is equally God, but that he understood an eternal standard that God is also eternally understanding, thereby achieving a union with God in the knowing of one divine idea. This is a union that provides momentary intellectual possession or "embrace" of an intelligible beauty, because the Forms are intelligible beauties. The quest for this possession is therefore moved by love in the sense of desire to possess beauty [erōs; caritas, amor].$^{43}$

Well then, which Form(s) did Augustine allegedly see? In div. qu. 46, where he says that only very few people can attain to contemplation of the Forms, the examples he gives are the Form of a human being and the Form of a horse. ${ }^{44}$ It will not be surprising if the answer is along these lines.

${ }^{42}$ Victorinus' gloss (Ad Cand. I4) occurs in the midst of an account of how the Son is generated from the Father, and this is also the context in Augustine's f. et symb. 4.6. Victorinus' presentation is notably like Plotinus' discussion of the One's "generation" of Divine Intellect in Enn. 6.7.15-17, except that Victorinus is arguing for consubstantiality. This similarity between Augustine's f. et symb. 4.6 and Victorinus' Ad Cand. I4 inclines me to the thesis of L. Ayres in his Augustine and the Trinity (Cambridge: Cambridge University Press, 20I0), 26-4I (partly citing Cipriani), that Augustine knew Victorinus' anti-Arian works from early on.

43 See footnote io.

${ }^{44}$ Cf. Plotinus, Enn. 5.I.4 lines 2O-2 I. This parallel between Augustine in De diversis quaestionibus and Plotinus (which was not noted by P. Henry, La vision d'Ostie: Sa place dans la Vie et l'Euvre de saint Augustin [Paris: Vrin, 1938]) suggests that Henry was right (on other grounds) to think that this (i.e., Enn. 5.I.4) played a role in 
It seems clear that, in Book 7 , it is the transcendent Form or pattern of a human being that Augustine is claiming to have seen. In conf. 7.IO.I6, he says that he saw that there was a contrast between the being that he contemplated and his own status as something in the realm of coming to be and passing away; and in conf. 7.17.23, he says that he turned his mind from sense-based representations and reflected on the power of reasoning, noting that reason is the specific difference of human beings. The latter statement evokes Plotinus's and Porphyry's method of attaining vision of the Form of oneself by abstracting from all images of one's accidental characteristics such as one's physical size (Enn. 5.8.9, 8.I I; Porphyry, Sent. 40). Furthermore, if what Augustine saw was the archetypal pattern of human being, then it would have been germane for him to mention his having been made by God according to this pattern; and in fact he does say that what he saw "made him."

As for the object of contemplation in the other ascent (conf. 9. (0.24), all we know is that it was the grasping of an eternal pattern of some created thing, as he indicates when he says that he ascended by wonder at the sun, moon, stars, and all mutable things and observed that all the things of creation say, "we did not make ourselves, but he made us who abides forever in eternity" (conf. 9.10.25). Augustine is again consistent with Neoplatonic methodology: in Enn. 5.8.9, Plotinus recommends starting from the sun, the moon, and the stars, and Porphyry cites the authority of Plato for starting the mystical ascent from the perceptible world, and continuing on to the intelligible. ${ }^{45}$

Given all this, the best way to understand Augustine's statements in conf. 7.Io.I 6 that he saw a light, the light had made him, one who knows this light knows the truth, and truth is God is that he means God is incidentally "seen" by anyone who "sees" a Form and who also knows that the Forms are in God's Mind. Anyone who has seen London has in fact seen England, since London is in England, despite the fact

Augustine's presentation in conf. 9.I0.24; see Henry in J. Pépin, "Ex Platonicorum Persona": Études sur les lectures philosophiques de Saint Augustin (Amsterdam: Adolf M. Hakkert, I977), I37, n. 4.

45 Porphyry, Marc. Io. If Porphyry's Ad Marcellam and Sententiae are being used by Augustine here, they are being used in conjunction with and secondarily to Plotinus. For, while Porphyry's texts do carry over Plotinus's terminology of "beings" for the Forms and his account of the contemplation of one's Form, they do not contain anything that we find in Augustine's accounts that is not already in Plotinus (see the sections titled "The Plotinian "Love" Context of All Three Ascent Passages", "Augustine Was Knowing One Divine Idea," and "Which Form(s) Did Augustine See?"|. Furthermore, some of the points of similarity between Augustine and Plotinus are not found in these Porphyrian works. 
that she has not seen the entirety of England. Similarly, if "the beings" are within God, then it will be true to say that whoever has seen a being has in fact seen God. Hence, because Augustine thinks that the beings or Forms are inside of God, he can address God as the locus of what he saw when he recounts his experiences. And because there are multiple Forms inside of God's Mind, no one of which exhausts the nature of God, he can say that he saw $a$ Form without contradicting his position that one must be completely purified and must die to see God's nature itself.

\section{CHRISTIAN OR NEOPLATONIC MYSTICISM?}

Some commentators have wanted to say that all of these so-called mystical experiences are in some way Christian as opposed to Neoplatonic. Augustine's statement that he was "lifted up" by God [tu adsumpsisti me] to one of the visions in Book 7, for example, might seem to be a particularly Christian ingredient. Is this not a case of his general insistence on the human being's need for grace and the insufficiency of the human will damaged by original sin to accomplish any worthwhile action? ${ }^{46}$ It turns out that the notion that seeing a Form requires divine aid is not particularly Augustinian or Christian, however; Plotinus himself describes ascent to Divine Intellect as a gift necessarily preceded by petitionary prayer (Enn. 5.I.6, lines 8-I2; 5.8.9, lines I3-I4). Notice, too, that Augustine presents his and Monnica's mystical experience in Book 9 without any suggestion of passivity on their part. He says that he and Monnica stretched themselves and thereby succeeded in touching "being" in eternal Wisdom (conf. 9.10.25, extendimus nos). This means that they willed to attain this vision; their ascent was moved by impulse to action. ${ }^{47}$ Plotinus similarly says that in order to see the content of Divine Intellect we must "stretch ourselves out with our soul" (Enn. 5.I.6, line Io)..$^{8}$

${ }^{6}$ Du Roy, L'Intelligence de la foi, 72, 76; O'Donnell, Augustine: Confessions, vol. 2, 437; cf. Boersma's comments on Augustine's De vera religione (G. Boersma, Augustine's Early Theology of Image: A Study in the Development of Pro-Nicene Theology, Oxford Studies in Historical Theology [Oxford: Oxford University Press, 2016], 225).

47 On will (voluntas) as impulse to action (the Stoic sense of horme-) in Augustine, Seneca, and Cicero, see Byers, Perception, Sensibility, and Moral Motivation, 88-99, 2I7-23I.

48 The parallel "stretching out" was noted in Pépin, "Ex Platonicorum Persona," I39, n. I. 
We might think instead that the "mystical experience" in Book 9, by which point both Augustine and Monnica are baptized Christians, is Christian in a way unlike those recounted in Book 7, which are Neoplatonic. Book 9, it has been suggested, describes a "hearing" rather than a "seeing," and there are biblical verses that mention "hearing." 49 But this contrast will not work, on two accounts. First, Augustine calls his first ascent in Book 7 a "hearing" in addition to a "seeing;" and he identifies himself and Monnica as being in the role of a "seer [spectator]" in Book 9. Second, Plotinus himself describes mystical ascent as "hearing voices from on high" (Enn. 5.I.I2, lines I5-2I). Perhaps, then, Augustine's ascent in Book 9, because it was with Monnica, is being presented as an experience of Christian community, rather than a Plotinian communing of the "alone with the Alone." ${ }^{50}$ But this contrast is complicated by the fact that in Porphyry we already have a model of a man and a woman united in contemplation of an intelligible Form/being (Porphyry, Marc. Io). If Augustine did not know this text, then it may be right that in Book 9 he intends to differentiate himself from what he knew of the Neoplatonists. Nevertheless it remains true that conceptually there is nothing particularly Christian about the idea of intimate friends jointly aiming for vision of the intelligible Forms.

In fact, the only substantive difference between Augustine and Neoplatonism here is one to which these commentators have not drawn attention. Augustine stipulates that the light in which he saw "being" "was superior because it made me, and I was inferior because I was made by it" (conf. 7.Io. I6). This sets him apart from Plotinus. The latter recommends, as part of the process of ascent, consideration of the fact that one's own soul itself made all the things in nature when it was with Plotinus' third God, Soul, prior to its fall into matter (Enn. 5.I.2-3). Thus, even when presenting the ascents prior to his baptism, in Book 7, Augustine insists upon a radical differentiation of creature from Creator. This is how he disagrees substantially from the Neoplatonic accounts that inspired him to attempt intellectual ascent to Divine Beauty.

49 O'Donnell, Augustine: Confessions, vol. 3, I 28, I 33.

${ }^{50}$ J. Rist, Augustine: Ancient Thought Baptized (Cambridge: Cambridge University Press, I994), 85, referencing Plotinus, Enn. 5.I.6. Cf. J. P. Kenney, Contemplation and Classical Christianity, I 5 I. 


\section{Further Reading}

Ayres, L. Augustine and the Trinity. Cambridge: Cambridge University Press, 2010.

Boone, M. "The Role of Platonism in Augustine's 386 Conversion to Christianity." Religion Compass 9/5 (May 2015), I5 I-I6I.

Brittian, C. "Attention Deficit in Plotinus and Augustine: Psychological Problems in Christian and Platonist Theories of the Grades of Virtue." Proceedings of the Boston Area Colloquium in Ancient Philosophy I8 (2003), $223-263$.

Byers, S. "Augustine and the Philosophers." In A Companion to Augustine, ed. M. Vessey. Oxford: Blackwell, 2012, I75-187.

Cooper, S. "The Platonist Christianity of Marius Victorinus." Religions 7/I22 (October I, 2016), I-24.

Kenney, J. P. Contemplation and Classical Christianity: A Study in Augustine. Oxford Early Christian Studies. Oxford: Oxford University Press, 2013.

Menn, S. Descartes and Augustine. Cambridge: Cambridge University Press, I998.

Rist, J. M. Augustine: Ancient Thought Baptized. Cambridge: Cambridge University Press, I994.

"Plotinus and Christian Philosophy." In The Cambridge Companion to Plotinus, ed. L. Gerson. Cambridge: Cambridge University Press, I996.

Sorabji, R. "Time, Mysticism, and Creation." In Augustine's Confessions: Critical Essays, ed. W. Mann. Oxford: Rowman and Littlefield, 2006, 209-235. 